\title{
Some Doubts about the Economic Analysis of the Flow of Silver to China in 1550-1820
}

\author{
Jacques Melitz ${ }^{1,2,3}$
}

Published online: 28 August 2018

(C) The Author(s) 2018

\begin{abstract}
The paper takes issue with the mainstream economic analysis of the enormous flow of silver into China in 1550-1820. First, I challenge the view that arbitrage between gold and silver in European trade with China was important except for one twenty-year spell. Next, I argue that had China imported gold, its history would have been much the same. I also dispute the idea that the persistence of the silver inflows from 1550 to 1820 implies any persistent disequilibrium, and I maintain that economic theory can easily accommodate the view that the inflow of silver into China sponsored growth in China.
\end{abstract}

Keywords Silver flows into China 1550-1820 · Silver/gold exchange rates · Transaction costs in international trade

JEL Classification $\mathrm{N} 1 \cdot \mathrm{N} 15 \cdot \mathrm{N} 25 \cdot \mathrm{F} 36 \cdot \mathrm{F} 41$

In these pages, I would like to express some doubts about the mainstream analysis of the enormous flow of silver to China in 1550-1820. These doubts will cover four separate topics: the importance of arbitrage between gold and silver; the inflow of silver rather than gold; the persistence of the silver inflow over centuries; and the effect of the inflow of silver on China itself.

On the first topic, the literature maintains that arbitrage between gold and silver is essential in explaining the inflow of silver into China. But the argument is thin. There is no question that the differences in the relative prices of gold and silver between China and the rest of the world played a critical part in explaining why silver continually

Jacques Melitz

j.melitz@hw.ac.uk

1 CREST and CEPII, Paris, France

2 CEPR, London, UK

3 Heriot-Watt University, Edinburgh, UK 
flowed in rather than gold. However, this does not mean that trade between the two metals mattered or even took place. The importance of arbitrage between the two is a separate empirical question. Indeed, the exaggerated role of arbitrage in discussing China assumes unusual proportions. Two of the most prominent contributors to the discussion, Flynn and Giràldez (2002), even go so far as to describe the two periods within the 1550-1820 stretch when the silver/gold ratios between China and the rest of the world became equal (once around 1640 and another around 1750) as two exceptional times of equilibrium between the stock and the demand for silver in China. They are nothing of the sort but simply times when arbitrage between the two metals could be ruled out as a factor in explaining the inflow of silver into China.

This basic point is easily explained at once. In case of profitable trade in third goods, silver will flow into the countries where the metal is relatively more valued than gold and gold will flow into the countries where it is relatively more valued than silver. However, these flows do not imply the profitability of trade between the two metals. This next profitability depends very significantly on the costs of transport, risks, insurance, political interferences such as tariffs, etc., associated with trade between the two metals, as well as on the differential in price between the two. Let us label all of the costs inhibiting arbitrage, transaction costs. Then persistently low international spreads between the price ratios of the two metals probably mean low transaction costs of two-way trade between them; persistently high spreads probably mean high transaction costs. If the spreads tend to narrow and subsequently to remain low, it is a good bet that arbitrage between the two metals plays a role. However, the spreads of themselves tell us little or nothing about the profitability of trade of either metal with third goods and therefore about the volume of inflow of either metal. Zero spreads do not spell equilibrium in any sense at all. Under this condition the world distribution of the two precious metals could continue to move in any direction because of the profitability of trade in third goods (with either metal serving to pay as their relative prices are the same). All we know is that arbitrage between the two metals would be unprofitable.

Secondly, the literature places enormous emphasis on the strict silver content of the inflow of precious metals. But had it been gold that flowed in instead or had it been a mix of the two, would Chinese history have differed significantly and why? Interestingly enough, in the mid-eighteenth century Hume posed the very same question for England: What difference would it make for the country if the composition of the inflow of gold and silver changed? His answer was that it would make no difference at all; all that counts is the aggregate inflow of money (Hume, "Of interest" [1752] in Rotwein (1970), ed., pp. 47-48). I will argue likewise for China that had gold flowed in rather than silver, Chinese history would have been much the same. Regardless of gold or silver, there would have been the same inadequate production of the metal at home, since the country was not a significant producer of either metal. Thus there would have been much the same need to produce silk, porcelain and tea in order to pay for the metal. Any clear difference from China's adherence to silver rather than gold as money comes after the study period, post-1870, when China became increasingly isolated as a money-user of silver, and with few and small exceptions other countries (including India by the beginning of the twentieth century) switched from silver or bimetallism to the gold standard in a world of rising international mobility of capital.

Third, there is a tendency in the discussion to view the Chinese data as implying long and persistent periods of excess demand for silver in China. However, this 
interpretation is problematic. It implies a long run tendency for the value of the metal to rise relative to other goods or a long period of deflation in terms of silver. Yet according to the usual measures, the consumer price level rose moderately in 1550-1700 and more than doubled in 1700-1800. As an alternative, I will argue that the data is consistent with long run equilibrium over $1550-1820$ as a whole with deviations, of varying lengths, positive and negative, and a fundamental regime change around 1700 , when the Xing, now in complete control of the political situation after the fall of the Ming dynasty in 1644, not only fully accepted silver as money, which the Ming never did, but also adopted an expansionary monetary policy as regards bronze coins. This alternative view seems at least as reasonable as the frequent one of a continuous disequilibrium in one direction.

Fourth and last, I will express doubts about the important tendency in the literature about Chinese imports of silver to minimize the impact of the imports on China. This tendency represents, I believe, an overreaction to the earlier Eurocentric view emphasizing the influence of Europe on the Far East. The overreaction takes two forms. One is to argue that China was simply too big for the inflows to matter much, especially if we consider strictly the inflows coming from Europe or its possessions in the New World (Goldstone 1991, pp. 371-2, is an example). Atwell (2005, pp. 469-470) has already responded well to this claim by pointing (largely with quotes from others) to the possibility that large concentrated effects on a small region of a big country would lead to broad changes in the rest of the country, in analogy to the way that any seed can spread (compare Marks 1997, pp. 129-30). However, a second part of the overreaction has gone unanswered. This part relies on the tradition since Hume, Smith and Ricardo to consider monetary events as bearing a strict influence on nominal events rather than real performance (Chaudhury 1978, pp. 156-9, was perhaps the first to suggest the point). It is indeed the case that this tradition says that in the long run, after all adjustments take place, the inflows of silver into China can only explain levels of money prices in the country. Thus, this tradition does indeed imply no impact of the inflow of silver into China on real economic performance, or in long run output, population, and living standards. However, though venerable, the tradition is also a very incomplete guide to what economics says about the question. ${ }^{1}$

Generally, monetary analysis recognizes but does not explore in any depth the historical margin from barter to money exchange; instead it centers on the monetized sector. The wholesale concentration on this sector holds for the Hume-Ricardo-Mill specie-flow mechanism, the Fisher and Cambridge versions of the quantity theory of money, and the monetary approach to the balance of payments, all of which receive great attention from economic historians. But the benefits of money exchange as opposed to barter have a long history in economics too and they tend to pop up readily in the introductory parts of elementary textbooks. Yet unfortunately these aspects of the topic have never been well integrated into the main corpus of monetary analysis. In these parts of the economic discussion, monetization is not just a matter of higher demand for money, but also one of reduced transaction and information costs, whose

\footnotetext{
${ }^{1}$ There are also passages in Hume and Smith, especially Hume, which contradict the tradition, as I will show in note 21 .
} 
effect on real economic activity, if anything, is often exaggerated by conjuring ahistorical situations where barter is almost unbelievably costly. ${ }^{2}$ On any close reading of Chinese monetary history, those sections of the economic literature are highly relevant.

\section{Arbitrage}

Something of the order of $80-85 \%$ of world production of silver in 1550-1800 came from the New World (Barrett 1990, Table 7, p. 225). Chaunu (1960, pp. 268-9) estimated that somewhat over one-third of the silver from the New World ended up in the "Extreme Orient," which means predominantly to China. That could make as much as around $27 \%$ of world output going to China altogether. That is an enormous percentage. According to the literature, arbitrage between gold and silver played a vital role in explaining this impressive phenomenon. Consider, for example, the following quotation from Richard von Glahn (2003, p. 197), perhaps the most widely cited expert on Chinese monetary history:

The gross disparity between the price of silver (measured in gold) in China and on the international market had been the source of the enormous arbitrage profits that was the impetus behind the massive drain of New World and Japanese silver in the sixteenth and seventeenth century. [A footnote reference to Flynn 1986 follows.] .... But the centuries-old disparity in silver/gold ratios came to an end in the middle of the eighteenth century. The price of silver (measured in gold) at Canton sank from 138 percent of the international price in the 1730 s to 97 percent in the 1750s, and remained roughly at par throughout the rest of the century. The parity between silver/gold exchange ratios in China and in the international market lends further support to the conclusion that supply and demand for silver in China were in stable equilibrium.

In the same vein, Flynn and Giràldez (2002, p. 395) describe the convergence of silver/ gold exchange ratios in China and the rest of the world around 1640 as meaning that "global shipments of silver were no longer motivated strictly by arbitrage considerations."

These are most curious statements.

Take any two countries, A and B, say, China and "Europe". From first principles, we know that if transactions costs of moving gold and silver between them are negligible, arbitrage will cause the silver/gold exchange ratios in the two to be little apart and to move together. If instead the transaction costs are non-negligible, arbitrage will set an upper and a lower bound to the difference between the two ratios. If the difference between the two falls outside the two bounds, arbitrage will tend to bring the ratios to the bounds. If the difference falls inside the bounds, arbitrage will be unprofitable and absent. On this basis, we can make two basic inferences. First, if the ratios of the two relative prices move in close harmony over time, arbitrage is very likely to operate since otherwise the result would be highly improbable, especially if the difference

\footnotetext{
${ }^{2}$ Indeed, mocking the exaggerated treatment of the costs of barter in economics has been a prominent sport of some anthropologists. An outstanding recent example is Graeber (2011, pp. 21-45).
} 
between the two is small. Second, if the two ratios move along separate paths, it is highly likely that transaction costs are large and we are mostly inside the bounds, where other factors than arbitrage explain the metallic flows.

Is there anything more we can say? In particular, can we say anything about the sign of the movements and the volumes? Indeed, we can make a strong prediction about the sign but can say little about the volumes. The sign should follow from the difference in relative prices. Suppose that the silver/gold exchange rate is lower in China than in Europe (less silver per unit of gold). Next, let us suppose that the export of any third good from China in return for silver is profitable to both China and Europe. Then whether or not the export of this third good in return for gold is also profitable to both, the sale for silver must be more profitable and will dominate. Therefore, silver will flow from Europe into China in preference to gold, no matter how wide or narrow the bands between the silver/gold price ratios are (never mind the slight bias in favor of shipping gold because it is the more valuable of the two metals and the less costly to transport). It follows that the difference between the two exchange ratios tells us nothing about the volume of the flow of silver from Europe into China but only about the sign. What about the possible impact of a movement in the difference in the exchange ratios between China and Europe? Suppose that the silver/gold exchange ratio rises in China relative to Europe, shouldn't the flow of silver into China fall? Indeed, it should, that is, if there is any arbitrage in the first place and if, in addition, it is the only or the dominant influence on the silver flow. Otherwise, if arbitrage is absent or there are many other influences besides it, some of similar or greater weight, then this is not the case.

Next, let us turn to the facts. Figure 1 juxtaposes estimates of annual silver inflows into China from the two main sources, Europe and Japan, at the top with values of silver/gold exchange ratios for China, Europe and Japan at the bottom for 1550-1820. (Unfortunately, the information about the exchange ratios for Japan, from Yamamura and Kamiki (1983), only goes from 1550 to 1639.) The reason for the end date of 1820 is that the flow of silver finally turned into an outflow at about that time. ${ }^{3} 1550-1820$ therefore marks a period of uninterrupted accumulation of silver from abroad in China. The data for the silver inflows comes from von Glahn (1996a, 2003) up to 1700 and from Yamamura and Kamiki (1983) beyond. These figures include strictly inflows of silver from production in Latin America or Japan. Like von Glahn and Yamamura and Kamiki, I treat all imports from Latin America, whether they arrive directly across the Pacific or indirectly via the Atlantic, as coming from Europe. For the silver/gold exchange ratios, the source is Peng (1993-4) for China and it is Soetbeer (1879) for Europe. Von Glahn (1996a) used Spooner's (1956, p. 339) data for France rather than Soetbeer's for Germany as a measure of the European silver/gold exchange ratios. But I prefer Soetbeer's data because it covers the entire study period while Spooner's data does not. Further, the two series are virtually identical over the years where they coincide. The notes to Fig. 1 contain more detail and the Appendix offers the exact numbers, going back to the fifteenth century and forward to 1850 in some cases.

As regards the silver/gold exchange rates, the series for China and Europe have been the focus of attention heretofore. If we judge from first principles alone, we can see from

\footnotetext{
${ }^{3}$ The outflow of silver in the 1820s came from two principal factors: opium imports and a political crisis in Mexico stemming the inflow of the silver Carolus peso coins into China, then-popular in China (Ma 2012 and von Glahn 2013, pp. 52-53).
} 
(a) ESTIMATED IMPORTS OF SILVER INTO CHINA 1550-1820

(Annual values in metric tons)
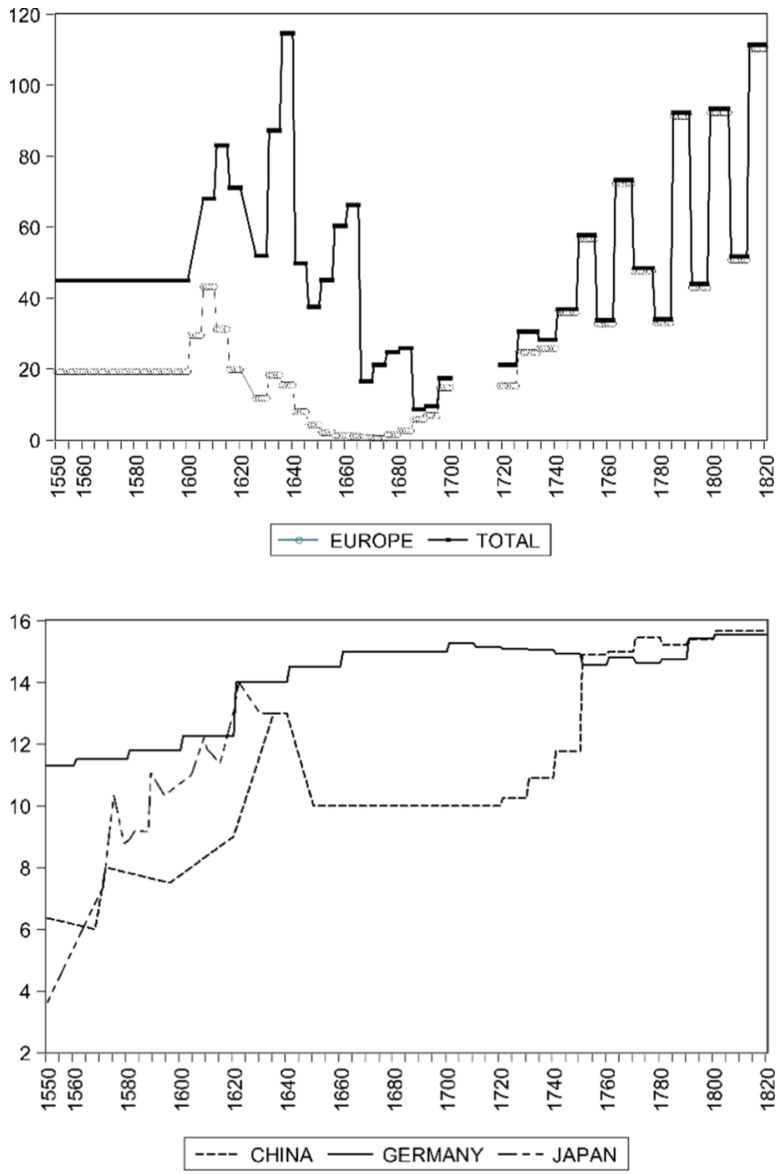

(b) SILVER/GOLD EXCHANGE RATIOS 1550-1820

Fig. 1 Note: The estimated imports of silver from Europe into China come, respectively, from von Glahn (1996a), Table 13, p. 140, for 1550-1600; same source, Table 23, p. 232, for 1601-1700; von Glahn (2003), Table 9.2, p. 195, for 1701-1806; and Dermigny (1964, II, p. 735) (von Glahn's source for 1701-1806) for 1807-1820. Those from Japan come from van Glahn (1996a), same tables as those for Europe for 1550-1700, and from Yamamura and Kamiki (1983), Table 7, p. 344 for 1701-1820. The silver/gold exchange rates for China come from Peng (1993-94), p. 608 for $1550-1635$, p. 768 for 1650-1700, p. 767 for 1701-1800, and p. 768 for 1801-20. These exchange rates also include one observation from Yamamura and Kamiki (1983), Table 9, p. 345: the one for 1637-1640. The silver/gold exchange rate for Germany, standing for Europe, all come from Soetbeer (1879), p. 123 for 1550-1680, and pp. 129-30 for 1681-1820. The silver/gold exchange ratios for Japan come from Yamamura and Kamiki (1983), Table 10, p. 346, except for 1630-39, which comes from Kobata (1965), p. 254. The Appendix contains the original data. It brings in more data and offers more detail about the estimated imports

the bottom of Fig. 1 that over 1750-1820, or at the end of the period, arbitrage between gold and silver between Europe and China is much in evidence. Beginning in 1750, the two ratios drew close together and subsequently moved in tandem. (See Deng 2008, p. 329 , for evidence that this continued for the rest of the nineteenth century.) However, up to 
1750, the graphs would mainly suggest instead wide bands between the arbitrage points of at least $50 \%$ most of the time. Perhaps arbitrage played a role in explaining why the bands were no wider. But even this need not be the case. The exchange rates could have been always within the upper and lower bounds for profitable arbitrage, while separate forces acted upon the two rates. The $1600-1650$ period is particularly interesting, since prima facie it gives the impression of no significant arbitrage between China and Europe, as we can hardly imagine that the arbitrage points between the two would have shrunk to virtually nothing from 1600 to 1640 only to return to their previous level in 1650 . (We will come back to this time stretch shortly.) Next, let us look at the top of Fig. 1 as well. The top traces the inflow of silver from Europe alone (via Latin America) and from both Europe and Japan (the larger of the two sources until 1685) together into China. It is plain at a glance that a higher positive percentage difference in the exchange rate in Europe (+) over the one in China (-) (greater arbitrage opportunities of moving silver to China and gold the opposite way) had no positive association with inflows of silver into China, neither from Europe nor from Europe and Japan combined. In fact, the correlation seems to go the other way: more profitable arbitrage opportunities seem to be associated with lower inflows of silver into China. Indeed, the statistical correlation between the arbitrage opportunities (the ratio of the European rate minus the Chinese rate to the Chinese rate) and the flow of silver into China is strongly negative. The coefficient is -0.65 for flows coming from Europe and -0.47 for the total inflows (from Europe and Japan combined) in 1550 to 1820 . If we prefer to focus on the period of 1600 to 1750 (because the gross profit rates from arbitrage are all near-zero from 1750 to 1820 and there is a single observation for inflows from 1550 to 1600 ), the two respective coefficients become -0.27 and -0.61 . Those results are also highly robust. ${ }^{4}$ This opposite relation clearly calls to mind the possibility of a negative supply effect of large inflows of silver into China on the price of silver relative to gold in the country (higher ratios of silver to gold) rather than anything to do with arbitrage. ${ }^{5}$ In conclusion, the raw data yields no evidence of arbitrage between gold and silver before 1750 . The only way to find out anything about the subject in the earlier years, $1550-1750$, is to examine the evidence further.

As a preliminary, note that arbitrage would require gold outflows from China corresponding to the silver inflows. Even such outflows, though, would not necessarily spell arbitrage. For example, the gold could go out from China to Europe in payment for woolens while the silver came in from Europe to pay for silk, without any arbitrage ever taking place between the metals. In this respect, we are lucky, however, since the Chinese hardly imported anything but silver from either Europe or Japan during the period (though it did import significant values of other goods from Southeast Asia and from Russia). Therefore, we can interpret any gold outflows from China toward Europe or Japan as reflecting arbitrage between gold and silver.

Flynn and Giràldez consistently emphasize arbitrage between the two metals between China and Europe in 1580-1640 in their many discussions of the subject (for

\footnotetext{
${ }^{4}$ The calculations rest on the values of the two variables at equally spaced intervals (every 5-6 years), whose number matches the number of observation points for silver/gold exchange rates that served in constructing the graphs from the data (in the Appendix, Table 2). However, raising or lowering the number of observations in the calculation within a reasonable range (2- to 10-year intervals) yields essentially the same results.

${ }^{5}$ Of course, any inflows of silver into China stemming from profitable arbitrage would also lower the price of silver in the country (raise the silver/gold rate in China), but that would only limit the positive impact of the profitable arbitrage on the inflows rather than reverse the signs.
} 
example, Flynn and Giràldez 1994, pp. 74-76, Flynn and Giràldez 1995a, p. 432, Flynn and Giràldez 1996a, p. 313, Flynn and Giràldez 1997, pp. XVI-XVII, and Flynn and Giràldez 2002, pp. 396-398). Nonetheless, to the best of my abilities to determine, there were no important European imports of Chinese gold in this period (which saw large European imports of gold and silver from the Peruvian and Mexican mines instead (Vilar 1974, p. 179)). The only important sale of gold in return for silver by China during this time was in trade with Japan and India, not Europe (see, for example, Kobata 1965 and Yamamura and Kamiki 1983 for Japan, and Souza 1986, p. 54, for India). ${ }^{6}$ Things differ for 1650-1750, when Chinese gold evidently flowed out to Europe fairly regularly. However, this flow remained fairly insignificant until the second half of the period, 1700-1750 and only became large and important around 1720-1740 (see Dermigny 1964, vol. 2, pp. 407-433). ${ }^{7}$ Thus, if I am correct, the period of $1700-1750$, perhaps more exactly $1720-1740$, is the only one in the whole 1550 1750 interval when arbitrage between Europe and China was important.

The 1580-1640 experience is of particular interest because at its close, in the early 1640s (perhaps as early as 1637), the silver/gold ratios in China and Europe drew together for the very first time since 1550 . However, as I have already intimated and will now try to show, this was sheer accident. ${ }^{8}$ The fundamental forces driving the Chinese exchange rate at the time were in the Far East.

In the first place, the equation of the two ratios in the early 1640s was an event of short duration, soon reversed. The European ratio had remained fairly still near 14 to 1 during the 1620-1640 interval and remained in the 14/15 range for the rest of the century (see Fig. 1). The Chinese ratio is the one that moved. It had been around 8 or 10 to 1 in the 1620s. It then rose to 13 to 1 in the late 30 s or early $40 \mathrm{~s}$, thus attaining the then-current level of 13.13 to 1 in the Spanish Empire (Cross 1983, p. 400, and Atwell 1982, p. 82). Next, however, the Chinese ratio fell right back to 10 to 1 in relatively short time, where it stayed for the rest of the seventeenth century. Von Glahn (1996b, p. 433) refers to the equation of the two ratios as "short-lived"; De Vries (2003, p. 95) describes it as "brief". 9 On the face of it, something may well have happened in and

\footnotetext{
${ }^{6}$ This is not to deny that some Chinese gold went to Europe in 1580-1640. The question is whether this gold ever amounted to much. Kobata (1965, p. 247) refers to such gold movement (p. 247), and Souza (1986) can be interpreted this way (p. 5) but both authors' emphasis is on movements of Chinese gold to other destinations in Asia. On the other hand, Attman (1981) never mentions any flow of Chinese gold to Europe in a book-length study of the flow of bullion between Europe and the East. Nor does Chuan (1997) in a summary treatment of trade between China and Europe. Nor do Yamamura and Kamiki (1983) in an important, much-cited piece where such flows would have been expected to appear if they mattered. Nor does von Glahn, not explicitly, though he does emphasize gold flows from China to both Japan and India (primarily Japan) in several places (von Glahn 1996a, pp. 129-30, 1996b, pp. 434-5, 2013, p. 36). For all of their own fuss about arbitrage, Flynn and Giráldez (2002, p. 398, note 13) themselves do not even necessarily disagree about the slight volumes in 1580-1640.

${ }^{7}$ In the omitted section in the previous quotation from von Glahn (2003), indicated by ellipses, he refers to this next incident and the evidence from Dermigny, as well the earlier incident (which he mentions with less precision).

${ }^{8}$ This would also not be first time that such an accident happened. Peng (1993-4, p. 765) observes that at several junctures, "gold-silver ratios of both sides [China and Europe] had converged during Song and Yuan times." However, he considers these convergences coincidences and independent of any arbitrage (next paragraph; see also p. 433).

${ }^{9}$ Yang (1952, p. 48) cites a ratio of silver/gold for China of 10 to one in 1662, and Peng (1993-4, p. 768) proposes an average ratio of 10 to 1 for the entire half century 1650-1700. Yet I have never seen any actual price quotations for the late $1640 \mathrm{~s}$ and $1650 \mathrm{~s}$.
} 
around China independently of Europe. In fact, Kobata (1965) and Yamamura and Kamiki (1983) confirm this possibility. As Kobata points out, at the end of the sixteenth century, silver/gold exchange rates in the Philippines, Sumatra, Siam and Indo-China in Southeast Asia were below the Chinese level. He quotes a ratio of 6 to 1 for northern Sumatra in 1610 (p. 255) as opposed to around 8 to 1 for China. The Japanese one at the time was around 11 to 1 (Yamamura and Kamiki 1983, p. 346). Then in the following years, through trade, including no doubt significant arbitrage, the exchange ratios in Southeast Asia, China and Japan converged and attained about 13 to 1 by 1640 for two reasons, both centered on Japan. One was the considerable increase in the supply of silver from Japanese mines that resulted from the important discoveries of new deposits of the metal in the country dating back to the 1530 s and the subsequent adoption of improved technology for separating the silver from lesser minerals. The other was that the rulers in Japan in the 1580s and in the first half of the sixteenth century decided to favor mining, even by exporting silver for other goods (compare Atwell 1982, pp. 68-72). Under these two influences, silver depreciated heavily in the whole region relative to gold. In the 1630s, Japan became an exporter of gold (Yamamura and Kamiki 1983, p. 350); thus the arbitrage between China and Japan ceased. The relevant trade, including the arbitrage while it lasted, consisted of the export of silver by Japan to China and Southeast Asia in return for purchases of gold and silk (mainly silk) from China and spices, sugar, silk and a range of other products from Southeast Asia. The trade was also carried largely, but by no means exclusively, by Portuguese ships. Very significantly, however, once Japan ceased to buy Chinese gold, the Chinese silver/gold exchange rate went right back from 13 to 1 to 10 to 1 levels in relatively short time. It is difficult to see what bearing the temporary merging of the Chinese rate with the European one has on all this.

As an interesting sidelight, India also became an important destination for Chinese gold in the 1620 s along with Japan. In that decade, the silver/gold exchange ratio rose in India from around 10/1 to the $12 / 1$ to $14 / 1$ range (Moosvi 1987, p.65) whereas the ratio remained in the 8 to 10 range in China. Consequently, some Chinese gold in the Southeast Asian trade headed for India instead of Japan, and this trade continued into the 1630s, when Japan had ceased to be a destination for any Chinese gold. Souza (1986, p. 54) provides convincing evidence of the importance of the movement of Chinese gold to India (another reputed "sink" for the world output of both gold and silver) in this interval. However, to all indication, this trade also ceased in the 1640s.

As regards the years 1650-1750, we may begin with the following two quotes (same page) from Peng (Peng 1993-4, p. 766):

During the last half of the seventeenth century, an ounce of gold cost 15 ounces of silver in Europe, but still only 10 in China. Once the European merchants who had come to China had taken care to acquire the goods they had come for, they would use the remainder of their money for Chinese gold jewelry, which made an excellent investment.

During the first century or so of Qing [thus approximately 1650-1750], there were few European merchant vessels which came to China without buying gold there, particularly with the private funds of the ships' officers. The East India Company regulated the goods that ships officers might carry. ... They were only permitted 
to bring gold and musk back from China because the space occupied by those articles was not great.

From these observations, we get the strong impression that arbitrage of the two metals between China and Europe from 1650 to 1700, while it existed, was not a primary objective. However, as regards 1700-1750, the story changes, mainly for 1720-1740. There is plain evidence (largely from Dermigny 1964, vol. 2) of European ships sailing out to the Far East with the express purpose of bringing back Chinese gold as a major part of the return cargo. Since the differences in the ratios of silver/gold prices in 1720 were still much the same as they had been since 1650, the arbitrage points must have narrowed. The impression of such narrowing is reinforced by the fact that the differences in the exchange ratios continued shrinking after 1720 , especially from 1740 onward, and after 1750, the ratios remained closely tied together, never to widen again, for the rest of the period.

The basic point, I believe, is that even a $50 \%$ difference between silver/gold exchange rates did not necessarily suffice to promote significant arbitrage. It is also not difficult to see why. De Vries (2003, p. 89) cites observed ratios of revenues to costs on imports from China, or ratios of sales price in Europe to purchase price in Asia, going from 3.4 to 1 in 1600 to 2.4 to 1 in 1750 for the European trading companies plying the Cape route to Asia as a group (Table 2.13). Chaudhury (1986, p.76) cites similar ratios of 2 to 4 to 1 on all imports from Asia to Europe for the English East India Company (EIC) in the first half of the eighteenth century. Yet, because of associated costs, even these enormous mark-ups only led to rates of return on capital of around $20 \%$, that is, on successful operations. According to Chaudhury (1978, p. 440), the annual profit rates of the East India Company for 1710 through 1745 peak at $22.2 \%$. Based on Chaudhury's data, De Vries calculates average rates of $12.5 \%$ in the $1710 \mathrm{~s}$ and $5.7 \%$ in $1736-1745$ (p. 91). ${ }^{10}$ One passage in Dermigny (1964, vol. 2, pp. 424425 ) is exceptionally to the point. There he focuses on ships carrying back gold from Canton to London between 1729 and 1741. For a sample of 16 vessels, he reports an average gross margin of $30 \%$ on imported gold (which would be consistent with silver/ gold exchange rates between 11 and 12 to 1 in China while they were 15 to 1 in Europe) and almost $150 \%$ for the rest of the merchandise, that is, 5 times higher. He does not report rates of profit. But it is quite clear from his discussion that as the price of gold rose relative to silver in China in the 1740s, which it did, the gold imports would be the ones to go first, not the rest. Two other pieces of evidence may be cited.

The EIC had evidently considered importing gold from China in the 1670 s as it was importing the metal from other parts of the East. But the company decided against it because, as Chaudhury explains (Chaudhury 1978, p. 181): "The duration of the

\footnotetext{
${ }^{10}$ The downward trend in the profit rate that De Vries singles out could be very important. In a more recent publication (De Vries 2010, pp. 722-726), he emphasizes increasing competition between the trading companies in the early decades of the eighteenth century as a factor. He also presents a more detailed range of ratios of sales to costs for 1700-1750 than he had earlier in 2003, going from 2.75 to 1.76 . This downward trend in gross margins might help to understand why gold became progressively more competitive with other Chinese goods as a European import over the period. To explain, suppose that ship cargoes had been optimally composed in 1700 , so that changing the composition in any way would bring down total profits. Then as gross returns on everything but gold fell, at some point the marginal return of including gold in the return cargo at the expense of something else would make it profitable to do so, even if the differential in the silver-gold exchange rate between Europe and China was unchanged.
} 
voyage from Europe to China and back was too long to permit a substantial margin of profit." He also quotes concordant opinion of contemporary EIC management dating as late as 1698. As the other piece of evidence, von Glahn (1996a) explains that much earlier, in 1609, when there were significant opportunities for profitable arbitrage of gold for silver between China and Japan, a Spanish official wrote that "if this [Chinese gold] was brought to New Spain, or to Castile, a profit of 75 or 80 percent would be made" (p. 130). However, von Glahn observes in passing that the plan "apparently did not win converts in Madrid" (p.131).

The point is clear. Space on ships is scarce. Carrying gold is at the expense of carrying something else. The revenues on any return voyage must cover all of the costs of administration, fixed capital, labor, security and risks at sea (or land), for the required time (at least 18 months and possibly two years) and none of these costs can be assigned to any single transported good but must still be met for the entire operation to be profitable. Therefore, even a $75-80 \%$ gross margin on gold, to say nothing of a $50 \%$ one might not suffice. In sum, the big stimulus for Chinese-European trade was silk for silver. ${ }^{11}$ The lure of arbitrage between gold and silver was a modest factor before 1700 or 1720 . Matters evidently changed in the 1750 s when arbitrage started to keep the silver-gold exchange rates between China and Europe from spreading apart on a continuous basis. Perhaps it became easier to exchange claims on silver and gold between Europe and China without physical movement of the metals. This has never been properly explained.

\section{Silver Versus Gold}

Next, I wish to call into question the importance that the literature accords to the Chinese import of silver rather than gold. There is an associated tendency to underline the contemporaneous European view of the Chinese in 1600-1640 as a people with an extraordinary thirst for silver. Some of the quotations are admittedly irresistible. According to one Portuguese missionary writing around 1637-1638 (Boxer 1970, p. 463) the Chinese merchants' attitude toward silver in Manila can be described as "Silver is blood." A Portuguese former colonial administrator writing around 1609 reports that the Chinese merchants in Manila would only accept silver in trade: "For they do not like gold, nor any other goods in exchange, nor do they carry any to China" (for example, Atwell 1982, p. 76). Notable too, even though neutral about predilections and tastes, is the analytical observation of a contemporary Portuguese merchant, dating 1621 (for example, von Glahn 1996c, p. 433): "Silver wanders throughout all the world in its peregrinations before flocking to China, where it remains as if at its natural center." But in interpreting all such statements, it is fundamental to keep in mind that the exchange rates favored importing silver to gold in China at the time. The Chinese

\footnotetext{
${ }^{11}$ Silk was a good of similarly high value relative to weight (and occupied space), and Ma (1999, p.61) cites 10 to 1 gross margins on silk travelling from Manila to Peru around 1620-21 in a broad historical study of the silk trade going far back to antiquity. However, Flynn and Giráldez (1995a, p. 434, 2002, p. 401, n.19) dispute such high ratios and consider 3 to 1 ratios far more likely. For a wealth of interesting information from many sources about the importance of trade of silk for silver in the seventeenth century, see Flynn and Giráldez (1996b).
} 
merchants could have been avid profit-seekers. Is there more to the matter? The evidence does not support it.

Even as recently as the early mid-sixteenth century, the silver/gold ratios between China and Japan had favored the import of gold and the export of silver in China in trade between the two countries for many decades. That is exactly what happened (Kobata 1965, p. 348, Yamamura and Kamiki 1983, pp. 329-342). Going back many centuries earlier in Chinese history, gold and silver emerged as monetary metals around 200 and 120 B.C., respectively (Peng 1993-4, pp. 102, 106, 144). But Peng observes (p. 359): "Prior to Song, gold had been more important than silver in China." Thus, for much of the 11 centuries following the unification of China in 221 B.C., gold had been the preferred of the two metals. Judging from the detailed discussion by von Glahn (1996a and 2013), the subsequent ascendance of silver over gold seems to be a case of path dependence. In Song times, China apparently acquired significant deposits of silver at several mines, particularly in Fujian. Thus, when the Song decided to introduce paper money around 1160 in order to economize on the transfer costs of metallic payments, they chose silver rather than gold as reserve backing. Subsequently, the Mongols accentuated this policy after coming to power in the thirteenth century. However, at some point in the Yuan (Mongol) dynasty's military effort to resist the Ming, the dynasty began to over issue paper money (silver certificates of sorts), and thereby caused silver to flow out of its coffers and the value of paper money to evaporate. In the aftermath of the Yuan's defeat in 1368, the Mings tried at first to maintain or revive the paper money experiment in the last quarter of the fourteenth century but failed. Subsequently, silver, not gold, provided the needed replacement for the large denominations of paper money that had vanished via inflation and popular disfavor. This happened despite efforts by the Ming dynasty to discourage the use of silver ingots as money in order to retain control over the money stock consisting otherwise of bronze coins. Eventually the Ming dynasty relented under the pressure of commercial interests, and as of 1583, the Ming even required silver in payment for a large part of taxes. All of this would seem to explain satisfactorily why silver spread rather than gold as money without invoking any Chinese predilection for one metal over the other, as is sometimes done. ${ }^{12}$

On the issue of the choice of metals, it is also important that gold could have served the Chinese just as well as silver as money. This is all truer when we consider that in either case they could have continued to use lesser metals for small change (to say nothing of their ability to adulterate either metal). As is widely emphasized by the experts in explaining the size of the inflow of silver into China in the relevant period (Atwell 1982, p. 79, Flynn and Giràldez 2002, p. 407, and von Glahn 1996a), Chinese population and output grew rapidly in the first couple of centuries of Ming rule. From 1450 to 1550 , population went from 88 million to 146 million; by 1820 , under the Xing, it was 381 million. As a proportion of world population, the rise was from $23 \%$ in 1450 to $35 \%$ in 1820. In terms of output, Maddison estimates (2003, Table B-20, p.

\footnotetext{
${ }^{12}$ The noted international economist Kindleberger (1989, p. 72) writes of a "Chinese passion for silver" and comments that "silver was as addictive as opium" (p. 69). For another example of this view, see Blitz (1967). But the view does not represent the profession (as Kindleberger recognizes himself). For example, Chaudhuri (1986, pp. 64-65) explicitly challenges all suggestion of any difference in mentality between Chinese and European populations in explaining the two's commercial behavior. Frank (1998) and Pomeranz (2000) take the same view.
} 
263) that the share of Chinese to world GDP went from $25 \%$ in 1500 to $29.2 \%$ in 1600 , dropped to $22.3 \%$ in 1700 , and went on to reach a staggering $32.9 \%$ in 1820 . Judging from those figures, it looks entirely reasonable that $27 \%$ of the world's output of silver would go to China in 1550-1820.

Of course, had China imported and monetized gold instead of silver, this would have promoted the domestic mining of gold rather than silver. But there are no striking differences in the country's ability to produce either metal. In general, China was not an important world producer of either one. Von Glahn (1996a, pp. 114-115) estimates that the country produced only as little as 10 to $15 \%$ of its imports of silver on the average during the 16 th and 17 th centuries. To all evidence, had China's monetary demand been for gold instead of silver in 1550-1820, the country's incentives to produce silk, porcelain and tea for export would have been similar since it would still have needed to rely predominantly on imports to meet its demand for money. ${ }^{13}$

The choice of gold or silver probably began to make a big difference sometime after 1870. As seen, by 1750 silver/gold exchange ratios between Europe and China had become nearly unified. From this time on, these ratios were essentially determined jointly. This alone need not have made much difference since it simply put China in the same position as it would have been had it used gold instead of silver or a combination of both as money. However, two interrelated events in 1870-1900 made it very important. First, there was a widespread adoption of the gold standard in the rest of the world. Second, the price of silver relative to gold dropped to levels never seen before in recorded human world history. From around 15 to 1 in 1870 , the ratio went to 33 to 1 by 1900 (it is currently above twice that level). This sharp rise in the relative price of gold worldwide meant a rise in China's import relative to its export prices in its commerce with countries on gold. But as almost the entire rest of the world went on to the gold standard progressively, by 1900 this rise in relative price pertained to virtually all of China's global trade (compare Wang 1992, p. 59). ${ }^{14}$ Accordingly, when the Great Depression took hold after the Market Crash of 1929 and many countries devalued their currency, China experienced a major appreciation of its currency at a time of falling world aggregate demand for goods. And soon afterwards in the early thirties, when the Western countries abandoned the gold standard and the US even went so far as to raise the price of silver (in US dollars) with the Silver Purchase Act of 1934, China experienced a big dive in its import prices and catastrophic rise in net imports, which forced it to go off of silver in late 1934. (See Friedman 1992 for some interesting discussion and further references.) But this was all well after 1820 , the end of our study period.

\footnotetext{
${ }^{13}$ In one interesting section of his extensive monetary history of China, Peng (1993-4, pp. 764-770) asks what difference it would have made for the purchasing power of money "if, beginning with the Ming, China had used gold instead of silver" (p. 768). His answer is that the value of money would probably have been more stable since gold prices were more stable than silver prices of rice during the time. This answer would seem to reflect the view that there would have been no structural difference in fundamentals, like population, output, and the profitability of trade, since otherwise Peng could not have drawn inferences from the observed price data without adjusting the data in any way that is, not correctly.

${ }^{14}$ For an econometric study of the responses of bilateral trade in Southeast Asia and other parts of the world to the switch to the gold standard in 1870-1914, see Mitchener and Voth (2011).
} 


\section{The Persistence of the Inflows}

Interestingly, China continued accumulating silver from 1550 to 1820. De Vries (2003. p. 96) offers the following explanation for this intriguing fact:

"The silver required to monetize the economy [China's] was enormous, and it became a moving target as population growth accelerated after the midseventeenth-century crisis. In the eighteenth century [my italics], China's population more than doubled (from 160 to 350 million)."

He adds (same page):

"The Asian market was so large, and its monetized sectors were expanding ... so rapidly, that the establishment of an equilibrium with Europe was ever out of reach."

There can be no doubt that the size and growth of the Chinese economy contributed greatly to its heavy imports of silver starting in 1550. Yet the Chinese population also shrunk from 160 million in 1600 to 123 million in 1650 , a half a century later (Maddison 1998, p. 169) and inflows of silver into China continued nevertheless. Could it be simply, as De Vries suggests, that the supply of silver in China in these years never caught up with the demand? The hole was too large to fill. This idea of a major long-term excess demand for silver in China links up with an important analytical point in Flynn (Flynn 1991, pp. 337-340) (see also Flynn and Giràldez 1996a, p. 320). He observes that large annual flows of a durable good like silver could constitute low percentages of the stock, whereas market equilibrium requires satisfaction of the stock-demand. Therefore the inflows of silver could continue for a long time before filling the demand. This could be especially pertinent concerning the imports of silver from Europe into China since the latter was the much bigger of the two (and hence the inflows of silver from Europe could be dwarfed by the desired stock). See Chaudhury 1986, p. 76, for a laudatory appraisal of this argument.

Notwithstanding, the idea of a continuous excess demand for silver in the period faces a basic problem: namely, it would imply continuous pressure toward the appreciation of silver, or deflation of consumer prices in terms of silver. ${ }^{15}$ On this ground alone, we can rule out the view altogether for the period of around 1680 or 1700 to 1820 , when the opposite took place and prices rose significantly

\footnotetext{
${ }^{15}$ As a matter of fact, Flynn himself adopts a different line of reasoning. According to him, there was a continuous excess supply of silver in China as well as the rest of the world in 1550-1650 stemming from profits in silver mining in Japan and the New World and the result was inflationary pressure everywhere. Eventually the fall in the world price of silver removed profits in silver mining and brought the process to an end (see Flynn 1986, pp. 42-47; 1991, pp. 337-340; and Flynn and Giràldez 1996a, p. 320). However, this alternative view fits uncomfortably with the dominant theme in the literature (often in Flynn's own writings, with and without Giràldez) that the steady flow of silver into China - however it may have begun — owed its persistence to the country's size and huge demand for money. Of importance, while De Vries and Flynn disagree about excess demand or excess supply, they clearly agree about long run disequilibrium. In my view, though, De Vries' position, emphasizing excess demand, or the Chinese demand pull on the world supply of silver (much like a "suction pump," according to a frequent image), reflects the literature much better.
} 
in China (see Peng 1993-4, p. 768, and von Glahn 2016, Fig. 8.5, p. 332). The price of rice is the usual index of the cost of living in China in the discussion. This price rose by a multiple of about 2.5 in terms of silver during the period (see Peng 1993-4, pp. 601, 752, for 1680 to 1800; von Glahn 2003, Table 9.1, p. 191, for 1800 to 1820 ; and compare with Wang 1992, pp. 57-58). What about the earlier period of 1550-1680/1700? To my mind, we need to split this period at least in two parts: roughly 1550 to 1600 and 1600 to 1680 or 1700 . For $1550-1600$, the idea of continuous pressure toward the appreciation of silver is reasonable and cannot be ruled out. But for 1600-1700, it can.

From 1550 to 1600 , the price of rice in terms of silver rose mildly $(\sim 15 \%)$, if at all (Peng 1993-4, pp. 601, 768). Some deflationary pressure is within the margin of error. ${ }^{16}$ In addition, an excess demand for silver should have raised the value of silver in terms of bronze coins. Here the statistical information I have seen is fragmentary (Vogel 1987, p. 17; von Glahn 1996a, pp. 106-107), but a rise in the price of silver relative to coins seems possible, at least for the latter part of the period, say, 1580-1600.

The difficulty regarding $1600-1700$ is fairly evident. From 1600 to 1650 , the population fell by nearly $25 \%$ as a result of warfare, including civil war, and the ultimate defeat of the Ming regime by the Xing in $1644 .^{17}$ This fall in population alone should have absorbed much, if not all, of any prior excess stock-demand for silver. In addition, von Glahn (1996a, p. 207) refers to "the catastrophic famine conditions of 1638-1642," Wang (1992, p. 66) describes the draughts that hit China four years in a row in 1641-1644 as "the worst in the last 500 years," and Marks (1997, pp. 147-51) refers to "the demographic crisis of 1648-53." Because of the sharp fall in aggregate supply of goods, the price of rice in terms of silver nearly doubled between 1620 and 1650 or thereabout, with little or nothing to do with monetary circumstances and monetary policy (and better viewed as stagflation rather than inflation). These same scarcity conditions produced a fall in the demand for money for small transactions, which led to a drop in the price of bronze coins by about half relative to silver. Notwithstanding, the aggregate demand for silver held up: imports persisted and even grew from 1626 to 1640 . Evidently this rise in demand for silver cannot be attributed to a desire to economize on transactions costs, but seems much more likely to reflect a desire to move to safety. The economic situation then reversed in agriculture in 1650-1660 to 1680-1700, or in the early decades of the Xing dynasty, as population either stabilized or grew, and the price of rice fell back close to its earlier levels in the first few decades of the seventeenth century, while the price of bronze coins relative to silver (von Glahn 1996a,

\footnotetext{
${ }^{16}$ Compare von Glahn 1996a, p. 159.

${ }^{17}$ Some writers consider that sixteenth-century prosperity persisted in South China under the Mings until 1620 (e.g., Souza 1986, p. 17; Frank 1998, p. 160). Others see brewing problems in the 1590s (e.g., Goldstone 1991 , p. 350). In dating the start of difficulties in 1600, I rely entirely on the population data from Liu and Wang (1979), pp. 81-82, Table A1 (which is repeated by Maddison 1998, Table D.1, p. 169, and by von Glahn (2003, Table 9.1, p. 191). This data shows a fairly steady $5 \%$ decline in population for China as a whole in every decade starting with 1600 before the fall of the Mings in 1644, and no notable acceleration of the fall in 1620. More recently, von Glahn (2016, Figure 8.3, p. 330) offers some new population data from two later sources for the same general period (same general trend); however, one series starts in 1620 and the other in 1630 .
} 
Fig. 11, p. 241) recovered heavily too. ${ }^{18}$ Imports of silver remained positive in this time, but fell from earlier levels in 1650-1680. On the whole, it does not seem plausible to ascribe the continuous inflow of silver in these tormented years to an inability of stock-supply to catch up with ever-increasing stockdemand for silver as a medium of exchange (not even if we add to this demand the one for silver for sensory pleasure and social status). A flight to safety seems much more apposite.

An alternative way of making sense of the imports of silver in the whole period $1550-1820$ is to view the market for silver in China as close to equilibrium the entire time but under different economic and political constraints, with some shifts in tendencies as well as short-run periods of excess supply and excess demand. The benefit of this mode of thinking is to avoid any sweeping idea of a continuous excess demand for silver. The mode of reasoning also invites a closer look at the facts.

Consider first the 1680-1820 stretch (for which I have more information than the 1700-1820 one). In this case there is only moderate difficulty in viewing the steady inflow of silver as yielding steady equilibrium in the market for silver. Wang (1992, pp. 64-65) estimates that silver stocks grew by .9 of $1 \%$ annually in this stretch while population grew by .72 of $1 \%$. Therefore, silver per capita grew by .18 of $1 \%$ annually. If we assume that per capita real output stayed the same, in line with Maddison (1998), then silver rose by the same in relation to output. This is consistent with some inflation. Yet, admittedly, inflation (measured on the basis of the price of rice in terms of silver) went too far for this explanation alone to suffice. Rice rose in price by a factor of 2.5 in these 140 years, corresponding to an annual rise of around .66 of $1 \%$, far above .18. However, we should also bring bronze coins into view. Once the Xing assumed full control of the country, as mentioned earlier, they took a much more favorable attitude than the Ming toward the minting of bronze coins as well as the monetary use of silver. To quote von Glahn (2003, p. 200) for the eighteenth-century part of the period: "[The] emission of bronze coins probably contributed more to the expansion of the money supply than did imports of foreign silver." He goes on to estimate that the increase in coins in silver-equivalents was nearly $50 \%$ higher than the imports of silver in 1740-1780. This would explain greater growth of the money supply than an estimate based on silver alone. Further still, Wang (1979) stresses the growth of private issues of cash notes (claims on coins) and silver notes in this time, though primarily in the tail-end of the period, especially 1800-1820 (compare Elvin 1973, pp. 293-4). Despite these added contributions to the money stock, however, all in all, it would still be difficult to argue that the money stock rose as much 0.66 of 1 $\%$ annually relative to output in 1680-1820 (more than three times as much as the rise in the silver component alone), and therefore the idea of a rough equilibrium in the money stock in the period probably needs to be reinforced by the hypothesis

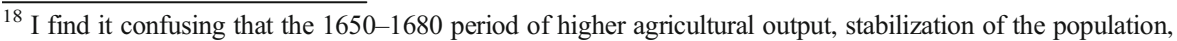
and falling agricultural prices is known in the literature as the "Kangxi depression" (granted the forcible relocation of the coastal population to deprive the Ming loyalists in Taiwan of a source of supply). The following quote from Wang (1992, p. 64) certainly gives a different impression: "After the establishment of the Manchu rule in 1644, peace and order were gradually restored in the country. ... The supply of grain became plentiful relative to the demand for food, despite the cold climate that prevailed in the latter part of the seventeenth century."
} 
of some fall in the desired real stock of money per capita. Yet such a fall could be plausibly attributed to a combination of three factors. First, output per capita probably fell, contrary to Maddison (see especially Broadberry et al. 2017 and also von Glahn 2016, pp. 350-9). Next, individual family size may have risen with the rapid growth of population. Both would mean less demand for real money per person. Last, the moderate development of finance (apart from the cash and silver notes forming part of the money supply) meant more money substitutes.

As regards the turbulent years 1600 to 1680 or 1700 , I have already indicated the need to admit a demand for silver as a refuge in times of distress and grave uncertainty. This necessity holds both for the period of the shrinking of the economy in 1600-1650 and the early part of the recovery. In this connection, the sharp fall of the imports of silver in the 1640-1680 part of the period (see Fig. 1) could be ascribed partly to progressively lower growth in the safety demand for silver.

The years 1550-1600 offer perhaps the least challenge since they were mostly peaceful, the population grew by around $10 \%$ and output roughly equally, while prices hardly rose. A rise in the stock-demand could then well explain the continuous inflows of silver. On the evidence, the inflows of silver might have been just right to meet the demand at current prices. Notwithstanding, De Vries' better-known view that the large inflows of silver in the period reflected a failure of the stock-supply to keep up with the stock-demand cannot be dismissed out of hand. This view probably fits better with the considerable rise in monetization of China, in conjunction with the large size of the Chinese economy, at the time. Yet the view implies steady deflation or upward pressure on the price of silver, which is not easy to defend.

\section{The Impact on China itself}

We come to the interesting question of the theoretical effect of the continuous inflow of silver on China itself. This question has so far been greatly overshadowed in the literature by the subordinate one of the respective weights of Europe and China in the outcome. A central feature of the recent scholarship on the monetary history of China is rebellion against the Eurocentric view of world monetary history that had prevailed only a few decades ago and that had treated Europe as the fundamental motor of world monetary events. As an arch example of this eurocentrism, Vilar's much-admired study of precious metals in world monetary history, Or et monnaie dans l'histoire (1974), devotes no more than 7 pages exclusively (112-19) to India, China and the Far East out of a total of 426. The rest is predominantly about Europe, its sources of precious metals, and the consequences for Europe itself. As another example, a more recent work titled The history of Money, by Davis (2002), which reaches back to primitive moneys and the birth of coinage in antiquity, contains only a sprinkling of references to China and India and no separate section on Central and East Asia except for the Westernization of Japan since 1878. The response of economic historians has been vigorous. Some modern scholarship even attempts to place Chinese demand for silver at the center of world monetary history in 1550-1820 (Flynn and 
Giràldez 1994, 1995b, pp. 217-8, 1996a, p. 311, 2002, pp. 419-20, Goldstone 1991, Frank 1998a). Unfortunately, one outstanding feature of this last literature is a tendency to underplay the reciprocal effect of the inflow of silver on China itself. As the argument goes, the income from the supply of silver to China made Spain and Japan rich, ${ }^{19}$ and the inflows of precious metals from the New World had a significant impact on money prices and economic activity in Europe, but China was simply too big to be much affected by the inflows. ${ }^{20}$ My main concern is with the use of monetary theory to defend this thesis. As noted in the introduction, the literature relies heavily on "neutrality propositions," as they are known in economics, about the strict nominal effects of the quantity of money on money prices in the long run. Accordingly, though he would be among the first to recognize the stimulating effect of the imports of silver on Chinese commercial activity, von Glahn (1996a) declares in the early pages (pp. 3-4) of his towering work: "The presumption that massive imports of silver were a boon to the [Chinese] economy finds little support in economic theory." It is clear, on close inspection, that all such claims refer to the economic analysis of changes in the quantity of money, and not the penetration of money exchange. Yet there is a profound difference, in economic analysis, between a change in the quantity of money in a monetized economy and a change in the monetization of an economy affecting the extent of production for home consumption and barter trade. The former does not alter the aggregate production function while the latter does. Monetary theory devotes far more attention to the former, but the latter may well be more relevant to the domestic impact of the inflows of silver into China.

To get the right perspective, let us suppose, to begin with, equilibrium in all markets for goods including real money balances and then a doubling of the nominal quantity of money and nothing else. In that case, apart from "money illusion," a doubling of all money prices (while all non-money nominal debt is indexed to the general price level) would necessarily keep equilibrium the same. Whether the economy will attain this new equilibrium or not and how, are major questions in the history of economic thought that have remained a focus of attention in economics right up to the present. Perhaps the outstanding conclusion is that the economy will reach the equilibrium under the right assumptions. As early as the mid-eighteenth and the early nineteenth century, Hume and Ricardo had already carried this principle of the neutrality of money to extremes. The least amount of precious metal will do as well as any other volume, they say; money prices would simply need to be correspondingly lower (Hume [1752] in Rotwein (1970), ed., pp. 47-59; Ricardo 1810). Decades later, John Stuart Mill intones: "There cannot, in short, be intrinsically a more insignificant thing, in the economy of a society, than money" (Mill 1848, p. 488). The traditional uses of the Fisher equation, the Cambridge analysis of the demand for money, and the monetary

\footnotetext{
${ }^{19}$ See Flynn (1991), who also argues, convincingly, that Spain misused its mineral wealth while Japan exploited it well.

${ }^{20}$ Frank takes an original position. He agrees that China profited greatly from the inflows of silver from the New World, but belittles the European contribution: "Europe was ... far too weak and marginal to have much impact on China" (Frank 1998b). On his view, China was able to profit from the silver inflows because of its high level of economic development and versatility. Europe, far more backward, could not cope with the inflows of precious metals without succumbing to inflation (Frank 1998a, pp. 157-8, 353).
} 
approach to the balance payments are all in tune with this position. But among the things that must stay constant in this reasoning is always the share of the economy using money, or monetization as such. ${ }^{21}$ Otherwise a reduction in transaction costs and costs of information would push the production possibility frontier of the economy outward. Already in 1944, Postan (1944) devoted an entire paper to alerting economic historians of the need to pay more attention to "the rise of a money economy," as distinct from "the greater abundance of money itself" (p. 129). More recently, in an extensive treatment of world financial structure since 1860 , Goldsmith $(1969$, p.304) asserted: "The proportion of the total goods and services that is monetized, in the sense of being paid for in money by the producer, is one of the most important characteristics of the level and course of economic development. It should be of major concern to economic historians." In economics, the sub-field of economic development is the main one to heed Postan and Goldsmith. The standard reference is Chandavarkar (1977). Since the latter wrote, the subject has tended to fuse with the broader issue of the impact of finance on the growth of developing countries (for example, McLaughlin and Kinoshita 2012), a fusion that Chandavarkar opposed. In monetary economics as such, much of the interest in monetization has been the association with reductions in information costs. A non-mathematical introduction with references to the literature is Goodhart (1989, pp. 1-50). There is a related, more abstract, literature on money as a coordination device (for numerous references, see Dubey et al. 2014)).

Once the issue is raised, the possible contribution of the flow of silver into China in 1550-1820 to monetization, and thereby its contribution to economic performance and economic growth, is almost obvious. As of 1550, China had a long history of cash in small transactions. However, apart from an impressive experiment with paper money in the 13th and 14th centuries, which ended miserably after some notable success, the country had a serious problem of money in large transactions. This problem clearly interfered with the integration of the different parts of the country's gigantic economy and probably necessitated heavy reliance on production for own consumption, barter transactions and tax payments in kind. In his highly condensed treatment of Chinese economic history, Maddison (1998) poses a picture of an economy that is very efficient in agriculture and land usage - far ahead of Europe in both regards even as late as 1820 - but hostile to manufacturing and commerce. This broad picture seems to fit in well

\footnotetext{
${ }^{21}$ Of note, references to "the inconveniences of barter" also have a venerable history in economic thought. A quick way to see this is to look up the term in the subject index of Monroe's (1923) work on monetary theory before Adam Smith ("barter, inconveniences of"). Indeed, Hume's essays, "Of Money" and especially "Of Interest" [1752], can be read as much as an argument for the importance of monetization as for the insignificance of the quantity of money. "Labour and industry gain life" (Rotwein 1970, ed., p. 37), he thinks, with the expansion of commerce, cities and manufacturing at the expense of agriculture and the landed interests, which he associates largely with non-market activity. The former is the source of energy, innovation, and saving; the latter the source of entrenched habit, consumption and debt. In the case of Smith (1776), apart from early references to the disadvantages of barter, pp. 22-24, the relevant part of The Wealth of Nations is the section discussing the local demand for silver in the New World, where he advances the view that before the opening of the mines, "their [the Peruvians'] whole commerce was carried on by barter, and there was accordingly scarce any division of labour among them" (p. 203). Jevons (1875) has become perhaps the standard historical reference on the inconveniences of barter (and much else about the benefits and desirable characteristics of money), even though he thought that barter no longer mattered much in the world of his time (p. 6)).
} 
with the general data on population, urbanization and agriculture. In 1550-1820, China's population grew by two and a half, if not more, while the European population barely doubled. This accomplishment took place despite the fact that the country had much less arable land per person than Europe did. The evidence is therefore consistent with special strength in agriculture. On the other hand, Europe saw a much higher rate of urbanization, as measured by population living in cities exceeding 10,000 (see De Vries 1984 for Europe and Rozman 1973, 1990 for China). This next evidence would seem to fit well with a lower development of manufacturing activities in China (even if Chinese rural households did engage in some manufacturing activities that typically took place in urban areas in Europe, such as textile spinning, weaving, and making clothing). The exceptional population growth in China, especially in 1700-1820, required a major shift of agricultural activities (begun centuries before) from the production of "subsistence crops" (which remained highly important), in terms of development economics, to "cash crops," like cotton, sugar, maize, peanuts, sweet potatoes, tobacco and tea. This major turn to cash crops in the 1550-1820 period is also well documented, as is the diversification of rural activities and growth in the number of regular, organized markets in the countryside (see Skinner 1964-5; Perkins 1969; Huang 1985; Marks 1997). All of this could only mean a shift to money trade. Cash transactions with bronze coins alone might also not have sufficed. The likely contribution of silver is clear. Payments in silver would have been useful not only in local trade but also, and especially, in permitting the large interregional movements that sale of the cash crops required. Silver would also have promoted the ability to specialize in commerce and wholesale activities.

The 1700-1820 period may require a special word since bronze coins developed far more than silver money at this time. Kuroda (2000) points to a deliberate effort by the Xing to renounce seigniorage on the coins, or even to subsidize them, in order to promote regional economic integration. Accordingly, the coins even began to serve in large economic transactions despite the costs of transport. Von Glahn (1996a, p. 254; 2002 , p. 59) refers to the use of coins in trade of land in 1750-1800. None of this sits well with my previous (and conventional) distinction between coins and silver ingots based on small and large denominations. Nevertheless, both Kuroda and von Glahn agree that the silver money underlay interregional payments and provided much of the glue for economic integration at the national level. Thus, for 1700-1820 as for the rest of the 1550-1820 interval, it would be difficult to argue that monetization in China could have evolved based on copper alone. Silver made an essential contribution too.

Peng (1993-4, pp. 570-1) and von Glahn (1996a, pp. 246-52; 1996b) point out another possible connection between the inflows of silver into China and aggregate economic performance. As mentioned earlier, the early Ming wanted to keep a strong hand over the total stock of money, and thereby the rest of the economy, and for this reason they fought the monetization of silver. Their eventual acceptance of silver money therefore represented a victory of the commercial interests. It freed up entrepreneurship and led to a more decentralized economy. Metzger (1979, p. 8) refers to the emergence of a "dynamism of the private sector" in Ming-Xing times. This could be a major added contribution, however difficult to assess.

In conclusion, I do not pretend to have shown that the inflow of silver raised aggregate output in any part of the 1550-1820 stretch. This would require more work and evidence (though, a priori, many specialists seem favorable to the idea (e.g., 
Rozman 1973, p. 34; Atwell 1982, pp. 84-85; Marks 1997, pp. 193-4, 334-5). I do claim that economic theory would support such a result and that the salient facts are amenable to it. $^{22}$

\section{Conclusion}

This paper takes issue with a number of prominent positions in the analysis of the flow of silver into China in 1550-1820. The outstanding problem is the failure to recognize the full significance of transaction costs. Because of these costs, arbitrage will only explain why the exchange ratios between gold and silver in distant places will approach a certain band. There is no market mechanism calling for equality of the exchange ratios within the band. Wide geographical differences in silver/gold price ratios are far better indications of high costs of arbitrage than opportunities for profitable arbitrage. The only evidence of major arbitrage between gold and silver in trade with China in 1550-1750 was concentrated in two periods: around 1580-1630, and around 17001750 (mainly 1720-1740). Only the 1720-1740 example clearly supports the idea that the import of Chinese gold into Europe was important for European trade with China. As other main points, the flow of silver rather than gold into China in the entire period 1550-1820 can be fundamentally interpreted as path dependence. Things could have easily gone differently. The strict silver composition of the inflows is also only of moderate significance for Chinese economic history in the period. In addition, the sustained inflow of silver into China in 1550-1820 cannot be explained as a continuous shortage of the metal. This explanation has its only possible merit in 1550-1600. A better interpretation is to view the steady inflow as providing the extra supply of the metal that was needed to keep the market in China at, or near, equilibrium under widely varying conditions, all of which called for an increase in the metal, but not always for the same reason. Finally, economic theory clearly admits the possibility that China profited from the inflow of silver. The inflow could have had such an effect by

\footnotetext{
${ }^{22}$ In their zeal to deny a Chinese advantage from the inflow of silver, Flynn and Giràldez (2000) claim that, if anything, China lost from the inflow because the country gave up valuable resources in exchange for mere money, a good that the country could have produced with paper at home. True, if the Chinese had mastered the art of monetary control of paper money (without borrowing the paper abroad), they would have been spared a lot of resources. But this is little relevant. Like the rest of the world, the Chinese had not learned the art, and in these circumstances, Flynn and Giràldez's view is difficult to defend. The Chinese merchants who bought the silver from foreigners clearly benefited from the trade, as did the Chinese people who bought the imported silver from the Chinese merchants. Any aggregate loss for China would depend on external diseconomies. But one can hardly imagine what these diseconomies would be. On the other hand, the contribution of the imported silver to Chinese aggregate wealth is easy to interpret: the imported silver represents a contribution to the present discounted value of future economies in transactions costs (and future benefits of safety, esthetic and other social satisfactions). True, the silver is no part of the productive capital at home, as the classical economists emphasized, but it does enter in the parameters of the social welfare function by increasing the outputs and utilities that result from given inputs (just as firm and household inventories of other goods do, by smoothing production and consumption over time, avoiding interruptions, and in other ways related to shopping and information costs). As a final note, this argument emphatically is not equivalent to mere reference to the inflows of silver as "increasing market activity," "greasing the wheels of trade," and the like. Such references are entirely compatible with strict short run effects on output that vanish after the adjustment of prices (as Hume had explained nicely in 1752; see Rotwein, (1970), ed., pp. 38-40, 57-59).
} 
promoting the retreat from production for own consumption, the retreat from barter, the integration of the national economy, and the independence of the private sector.

\section{Appendix}

Table 1 Estimated imports of silver into China 1550-1820 (annual values in metric tons)

\begin{tabular}{|c|c|c|c|}
\hline Period & Europe $^{\mathrm{a}}$ & Japan $^{\text {b }}$ & Total \\
\hline $1550-1600$ & 19.28 & 25.6 & 44.88 \\
\hline $1601-1605$ & 29.5 & & \\
\hline $1606-1610$ & 43.2 & 24.8 & 68 \\
\hline $1611-1615$ & 31.2 & 51.8 & 83 \\
\hline $1616-1620$ & 19.8 & 51.3 & 71.1 \\
\hline $1621-1625$ & & 57.3 & \\
\hline $1626-1630$ & 11.6 & 40.3 & 51.9 \\
\hline $1631-1635$ & 18.3 & 68.9 & 87.2 \\
\hline $1636-1640$ & 15.4 & 99.2 & 114.6 \\
\hline $1641-1645$ & 7.9 & 41.8 & 49.7 \\
\hline $1646-1650$ & 4.3 & 33.3 & 37.6 \\
\hline $1651-1655$ & 2.1 & 43 & 45.1 \\
\hline $1656-1660$ & 1.2 & 59.3 & 60.4 \\
\hline $1661-1665$ & 1.1 & 65.1 & 66.2 \\
\hline $1666-1670$ & 0.7 & 15.8 & 16.5 \\
\hline $1671-1675$ & 0.4 & 20.8 & 21.2 \\
\hline $1676-1680$ & 1.5 & 23.2 & 24.7 \\
\hline $1681-1685$ & 2.6 & 23.2 & 25.8 \\
\hline $1686-1690$ & 5.9 & 2.7 & 8.6 \\
\hline $1691-1695$ & 6.8 & 2.7 & 9.5 \\
\hline $1696-1700$ & 14.7 & 2.7 & 17.4 \\
\hline $1701-1705$ & & 7.5 & \\
\hline $1706-1710$ & & 6.6 & \\
\hline $1711-1718$ & & 4.1 & \\
\hline $1719-1725$ & 15.2 & 6 & 21.2 \\
\hline $1726-1733$ & 24.5 & 6 & 30.5 \\
\hline $1734-1740$ & 25.7 & 2.5 & 28.2 \\
\hline $1741-1748$ & 35.9 & 1 & 36.9 \\
\hline $1749-1755$ & 56.6 & 1 & 57.6 \\
\hline $1756-1762$ & 32.8 & 1 & 33.8 \\
\hline $1763-1769$ & 72.3 & 1 & 73.3 \\
\hline $1770-1777$ & 47.4 & 1 & 48.4 \\
\hline $1778-1784$ & 33.1 & 1 & 34.1 \\
\hline $1785-1791$ & 91.3 & 1 & 92.3 \\
\hline $1792-1798$ & 42.9 & 1 & 43.9 \\
\hline
\end{tabular}


Table 1 (continued)

\begin{tabular}{lllr}
\hline Period & Europe $^{\mathrm{a}}$ & Japan $^{\mathrm{b}}$ & Total \\
\hline $1799-1806$ & 92.4 & 1 & 93.4 \\
$1807-1813$ & 50.7 & 1 & 51.7 \\
$1814-1820$ & 110.4 & 1 & 111.4 \\
\hline
\end{tabular}

${ }^{a}$ The estimated imports of silver from Europe into China all come from von Glahn except for the last two observations, which come Dermigny (1964), II, p. 735). They are all sums of inflows via the Philippines and via the Indian Ocean. All the original data from von Glahn and Dermigny covered multiple-year intervals and needed to be annualized. Thus, for the period 1550-1600, Glahn's (1996a, Table 13, p. 140) figures for the Philippines and the Indian Ocean were added and then divided by 50. For 1601-1700, von Glahn offers quinquennial data (1996a, Table 23, p. 232) for the Philippines and the Indian Ocean. Therefore, the two were added and divided by 5. For 1719-1806, von Glahn (2003, Table 9.2, p. 195) offers annualized data for the sums of the inflows covering 6- or 7-year stretches. The data were simply copied. Von Glahn's data leaves open two gaps for the study period 1550-1820, for 1701-1718 and for 1807-20. I was able to do nothing to about the former, but I could cover the latter by going back to his source for 1719-1806, Dermigny (1964)

${ }^{\mathrm{b}}$ For $1550-1700$ the estimated imports of silver from Japan into China all come from the same Tables as those in von Glahn (1996a) for the earlier imports from Europe. They posed the same need to annualize. For 17011820, however, von Glahn offers no data. Therefore, I turned to Yamamura and Kamiki (1983), Table 7, p. 344, and used their preferred estimate, from Iwahashi (they offer one other). It was possible to check the coherence of the Iwahashi figures from Yamamura and Kamiki with those from von Glahn because of an overlap. Yamamura and Kamiki provide an Iwahashi estimate for 1601-1694, which could then be compared with the quinquennial estimates von Glahn provides for the same years. The annualized values in both cases are nearly identical. The only remaining problem then was to annualize the estimates that Yamamura and Kamiki offer for 1695-1709, 1710-1713, 1714-35 and 1736-1817 and next to recalculate annual averages for the same intervals that von Glahn offers for Europe

Table 2 Silver/gold exchange ratios ca. 1430-1850

\begin{tabular}{|c|c|c|c|c|c|}
\hline Period & China $^{\mathrm{a}}$ & Germany $^{\mathrm{b}}$ & Period & Japan $^{\mathrm{c}}$ & Spanish Empire ${ }^{\mathrm{d}}$ \\
\hline 1431 & 6 & & 1447 & 4.04 & \\
\hline 1475 & & 10.99 & & & \\
\hline 1480 & & 11.56 & & & \\
\hline 1481 & 7 & & & & \\
\hline 1483 & & 11.68 & & & \\
\hline 1497 & & 10.76 & $1497-1536$ & & 10.11 \\
\hline $1501-1520$ & & 10.75 & & & \\
\hline 1502 & 9 & & & & \\
\hline $1521-1540$ & & 11.25 & $1537-1565$ & & 10.61 \\
\hline 1530 & 6 & & 1540 & 3.62 & \\
\hline 1534 & 6.36 & & $1566-1608$ & & 12.12 \\
\hline $1541-1560$ & & 11.3 & 1571 & 7.37 & \\
\hline $1561-1580$ & & 11.5 & 1575 & 10.34 & \\
\hline 1568 & 6 & & 1579 & 8.77 & \\
\hline 1572 & 8 & & 1581 & 8.92 & \\
\hline 1581-1600 & & 11.8 & 1583 & 9.19 & \\
\hline 1596 & 7.5 & & 1588 & 9.15 & \\
\hline
\end{tabular}


Table 2 (continued)

\begin{tabular}{|c|c|c|c|c|c|}
\hline Period & China $^{a}$ & Germany $^{\mathrm{b}}$ & Period & Japan $^{\mathrm{c}}$ & Spanish Empire $^{\mathrm{d}}$ \\
\hline $1601-1620$ & & 12.25 & 1589 & 11.06 & \\
\hline 1620 & $8-10$ & & 1594 & 10.34 & \\
\hline $1621-1640$ & & 14 & 1604 & 10.99 & \\
\hline 1635 & 13 & & 1609 & 12.19 & \\
\hline $1637-1640$ & 13 & & 1609-1642 & & 13.13 \\
\hline $1641-1660$ & & 14.5 & 1610 & 11.84 & \\
\hline $1650-1700$ & 10 & & 1615 & 11.38 & \\
\hline $1661-1680$ & & 15 & 1620 & 13.05 & \\
\hline $1681-1700$ & & 15 & 1622 & 14 & \\
\hline $1701-1710$ & 10 & 15.27 & $1630-1639$ & 13 & \\
\hline $1711-1720$ & 10 & 15.15 & $1643-1686$ & & 15.45 \\
\hline $1721-1730$ & 10.25 & 15.09 & $1687-1728$ & & 16.60 \\
\hline $1731-1740$ & 10.9 & 15.07 & $1729-1750$ & & 16 \\
\hline $1741-1750$ & 11.77 & 14.93 & & & \\
\hline $1751-1760$ & 14.9 & 14.56 & & & \\
\hline $1761-1770$ & 15 & 14.81 & & & \\
\hline $1771-1780$ & 15.47 & 14.64 & & & \\
\hline $1781-1790$ & 15.23 & 14.76 & & & \\
\hline $1791-1800$ & 15.4 & 15.42 & & & \\
\hline $1800-1850$ & 15.63 & & & & \\
\hline $1801-1810$ & & 15.61 & & & \\
\hline $1811-1820$ & & 15.61 & & & \\
\hline $1821-1830$ & & 15.8 & & & \\
\hline
\end{tabular}

${ }^{a}$ Source: Peng (1993-4), pp. 607-8 for 1431-1635, p. 768 for 1650-1700, p. 767 for 1701-1800, and p. 768 for 1801-50. Yamamura and Kamiki (1983), Table 9, p. 345, for 1637-40

b Source: Soetbeer (1879), p. 120 for 1475-97, p. 123 for 1550-1680, and pp. 129-30 for 1691-1830

${ }^{\mathrm{c}}$ Source: Yamamura and Kamiki (1983), Table 10, p. 346, for 1437-1622; Kobata (1965), p. 254, for 1630-39

${ }^{\mathrm{d}}$ Source: Cross (1983), p. 400

Open Access This article is distributed under the terms of the Creative Commons Attribution 4.0 International License (http://creativecommons.org/licenses/by/4.0/), which permits unrestricted use, distribution, and reproduction in any medium, provided you give appropriate credit to the original author(s) and the source, provide a link to the Creative Commons license, and indicate if changes were made.

\section{References}

Attman A (1981) The bullion flow between Europe and the east 1000-1750. Kungl. Vetenskaps-och Vitterhets-Samhället, Goteborg

Atwell W (1982) International bullion flows and the Chinese economy circa 1530-1650. Past and Present 95: 68-90

Atwell W (2005) Another look at silver imports into China, ca. 1635-1644. Journal of World History 16(4): 467-489 
Barrett W (1990) World bullion flows 1450-1800. In: Tracy JD (ed) The rise of merchant empires: long distance trade in the early modern world. Cambridge University Press, Cambridge, pp 224-254

Blitz R (1967) Mercantilist policies and the pattern of trade, 1500-1750. J Econ Hist 27(1):39-55

Boxer CR (1970) Plata es sangre: sidelights on the drain of Spanish-American silver in the Far East, 15501700. Philipp Stud 18(3):457-478

Broadberry S, Ghan H, Li DD (2017) China, Europe and the Great Divergence: A study in historical national accounting, 980-1850. University of Warwick Working Paper no. 324, April 17

Chandavarkar A (1977) Monetization of developing economies. International Monetary Fund Staff Papers 24(3):665-721

Chaudhury K (1978) The trading world of Asia and the English East India company, 1660-1760. Cambridge University Press, Cambridge

Chaudhury K (1986) World silver flows and monetary factors as a force in international economic integration 1658-1758. In: Wolfram Fischer R, McGinnis M, Schneider J (eds) The emergence of a world economy. Frank Steiner Verlag, Wiesbaden, pp 61-82

Chaunu P (1960) Les Philippines et le pacifique des ibériques (XVI ${ }^{\mathrm{e}}, \mathrm{XVII}$, XVIII ${ }^{\mathrm{e}}$ siècles). S.E.V.P.E.N, Paris

Chuan H-S (1997) Trade between China, the Philippines and the Americas during the sixteenth and seventeenth centuries. In: Flynn D, Giràldez A (eds) Metals and monies in an emerging global economy. Ashgate Publishing Co, Aldershot, pp 281-285

Cross H (1983) South American bullion and export. In: Richards JF (ed) Precious metals in the late medieval and early modern worlds. North Carolina Academic Press, Durham, pp 397-423

Davis G (2002) A history of money. University of Wales Press, Cardiff

Deng K (2008) Miracle or mirage: foreign silver, China's economy and globalization from the sixteenth to the nineteenth centuries. Pac Econ Rev 13(3):320-358

Dermigny L (1964) La Chine et l'Occident: Le commerce à Canton au XVIIIe siècle 1719-1833. S.E.V.P.E.N, Paris

De Vries J (1984) European urbanization. Methuen, London, pp 1500-1800

De Vries J (2003) Connecting Europe and Asia: a quantitative analysis of the cape-route trade, 1497-1795. In: Flynn D, Giràldez A, von Glahn R (eds) Global connections and monetary history, 1470-1800. Ashgate, Aldershot, pp 35-106

De Vries J (2010) The limits of globalization in the modern world. Econ Hist Rev 63(3):710-733

Dubey P, Sahi S, Shubik M (2014) "Minimally complex exchange mechanisms: Emergence of prices, markets and money," Cowles Foundation Discussion Paper no. 1945, April

Elvin M (1973) The pattern of the Chinese past. Stanford University Press, Stanford

Flynn D (1986) The microeconomics of silver and east-west trade in the early modern period. In: Fischer W, Marvin McGinnis R, Schneider J (eds) The emergence of a world economy. Frank Steiner Verlag, Wiesbaden, pp 37-60

Flynn D (1991) Comparing the Tokugawa Shogunate with Hapsburg Spain: two silver-based empires in a global setting. In: Tracy J (ed) The political economy of merchant empires. Cambridge University Press, Cambridge, pp 332-359

Flynn D, Giràldez A (1994) China and the manila galleons. In: Latham AJH, Kawakatsu H (eds) Japanese industrialization and the Asian economy. Routledge, London, pp 71-90

Flynn D, Giràldez A (1995a) Arbitrage, China, and world trade in the early modern period. J Econ Soc Hist Orient 38(4):429-448

Flynn D, Giràldez A (1995b) Born with a 'silver spoon': the origin of world trade in 1571. Journal of World History 6(2):204-221

Flynn D, Giràldez A (1996a). China and the Spanish Empire, Revista da Historia Económica, XIV (2), pp. 309-38

Flynn D, Giràldez A (1996b) Silk for silver: manila-Macao trade in the $17^{\text {th }}$ century. Philipp Stud 44(1):52-68 Flynn D, Giràldez A (1997) Introduction, in Flynn, Dennis and Arturo Giràldez eds., Metals and Monies in an Emerging Global Economy, Aldershot, UK: Ashgate Publishing Co., pp. XV-XL

Flynn D, Giràldez A (2000) Money and growth without development: the case of Ming China. In: Latham AJH, Kawakatsu H (eds) Asia Pacific dynamism 1550-2000. Routledge, London, pp 199-215

Flynn D, Giràldez A (2002) Cycles of silver: global economic unity through the mid-eighteenth century. Journal of World History 13(2):391-427

Frank AG (1998a) ReORIENT: global economy in the Asian age. University of California Press, Berkeley

Frank AG (1998b) A review of Richard von Glahn, fountain of fortune: money and monetary policy in China, 1000-1700. Journal of World History 9(1):121-125

Friedman M (1992) Franklin D. Roosevelt, silver, and China. J Polit Econ 100(1):62-83 
Goldsmith R (1969) Financial structure and development. Yale University Press, New Haven

Goldstone J (1991) Revolution and rebellion in the early modern world. University of California Press, Berkeley

Goodhart C (1989). Money, Information and Uncertainty, 2d. edition: Cambridge, the MIT Press

Graeber D (2011) Debt: the first 5000 years. Melville House pub, Los Angeles

Huang PCC (1985) The peasant economy and social change in North China. Stanford University Press, Stanford

Jevons WS (1875) Money and the mechanism of exchange. Kegan Paul, Trench, Trübner \& Co., Ltd., London

Kindleberger C (1989) Spenders and hoarders: the world distribution of Spanish American silver 1550-1750. Institute of Southeast Asian Studies, Singapore

Kobata A (1965) The production and uses of gold and silver in sixteenth- and seventeenth-century Japan. Econ Hist Rev 18(2):245-266

Kuroda A (2000) Another monetary economy: the case of traditional China. In: Latham AJH, Kawakatsu H (eds) Asia-Pacific dynamism, 1500-2000. Routledge, London, pp 187-198

Liu PKC, Hwang KS (1979) Population change and economic development in mainland China since 1400. In: Hou C-M, Tzong-Shiang Y (eds) Modern Chinese Economic History (proceedings of a conference). Institute of Economics, Taipei, pp 61-90

Ma D (1999) The great silk exchange: how the world was connected and developed. In: Flynn D, Frost L, Latham AJH (eds) Pacific and Pacific rim economies since the $16^{\text {th }}$ century. Routledge, London, pp 38 69

Ma D (2012). Money and monetary system in China in the $19^{\text {th }}-20^{\text {th }}$ century: An overview, London School of Economics Working Paper no. 159/12, January

Maddison A (1998) Chinese economic performance in the long run. OECD, Paris

Maddison A (2003) The world economy. OECD, Paris

Marks R (1997) Tigers, Rice, silk and silt: environment and economy in late imperial South China. Cambridge University Press, Cambridge

McLaughlin C and Kinoshita N (2012) Monetization in low- and middle-income countries, International Monetary Fund Working Paper WP/12/160, June

Metzger T (1979) On the historical roots of economic modernization in China. In: Hou C-M, Tzong-Shiang Y (eds) Modern Chinese Economic History (proceedings of a conference). Institute of Economics, Taipei, pp 3-14

Mill JS (1848) Principles of Political Economy, London: Longmans, Green and Co. 1936 reprint of the last edition dating 1871 (edited by W.J. Ashley)

Mitchener K, Voth H-J (2011) Trading silver for gold: nineteenth-century Asian exports and the political economy of currency unions. In: Barro R, Lee J-W (eds) Costs and benefits of economic integration in Asia. Oxford University Press, Oxford, pp 126-156

Monroe A (1923). Monetary Theory before Adam Smith, New York: August M. Kelley, 1966 reprint

Moosvi S (1987) The silver influx, money supply, prices and revenue-extraction in Mughal India. J Econ Soc Hist Orient 30(1):47-94

Peng W (1993-4) A Monetary History of China, Bellingham: Center for East Asian Studies, Western Washington University (translated by Edward Kaplan). Vol. 1 (1993), vol. 2 (1994). Original version in Chinese, 1958

Perkins DH (1969) Agricultural development in China. Aldine Pub. Co., Chicago

Pomeranz K (2000) The great divergence: China, Europe and the making of the world economy. Princeton University Press, Princeton

Postan MM (1944) The rise of a money economy, The Economic History Review, 14, pp. 123-34, reprinted in E.M. Carus-Wilson, ed., Essays in Economic History Reprints Edited for the Economic History Society, vol. 1, 1954, pp. 1-12

Ricardo D (1810) The High Price of Bullion, London, 3d ed.

Rotwein E (1970) ed. David Hume Writings on Economics, Madison: University of Wisconsin Press. Original publication of the writings by Hume in 1752

Rozman G (1973) Urban networks in Ch'ing China and Tokugawa Japan. Princeton University Press, Princeton

Rozman G (1990). "East Asian urbanization in the nineteenth century: comparisons with Europe," in Ad Van Der Woude, Jan De Vries, and Akira Hayami, eds, Urbanization in history, Oxford: Clarendon Press, pp. $61-73$

Skinner GW (1964-5) Marketing and social structure in rural China, Journal of Asian Studies, 24, Part I (Nov. 1964), pp. 3-43, Part II (Feb. 1965), pp.95-228, and Part III (May 1965), pp. 363-99 
Smith A (1776) An inquiry into the nature and causes of the wealth of nations. The Modern Library (edited by Edwin Cannan, New York, p 1937

Soetbeer A (1879) Edelmetall-Produktion und Werthverhältniss zwischen Gold und Silber seit der Entdeckung Amerika's bis zur Gegenwart. Justus Perthes, Gotha

Souza G (1986) The survival of empire: Portuguese trade and Society in China and the South China Sea 16301754. Cambridge University Press, Cambridge

Spooner F (1956) L'économie mondiale et les frappes monétaires en France 1493-1725. Armand Colin, Paris Vilar P (1974) Or et monnaie dans l'histoire. Flammarion, Paris

Vogel HU (1987) Chinese central monetary policy, 1644-1800. Late Imperial China 8(2):1-51

Von Glahn R (1996a) Fountain of fortune: money and monetary policy in China 1000-1700. University of California Press, Berkeley

Von Glahn R (1996b) Comment on 'arbitrage, China and world trade in the early modern period. J Econ Soc Hist Orient 39(3):365-367

Von Glahn R (1996c) Myth and reality of China's seventeenth-century monetary crisis. J Econ Hist 56(2):429454

Von Glahn R (2003) Money use in China and changing patterns of global trade in monetary metals, 15001800. In: Flynn D, Giràldez A, von Glahn R (eds) Global connections and monetary history, 1470-1800. Ashgate, Aldershot, pp 187-205

Von Glahn R (2013) Cycles of silver in Chinese monetary history. In: So BKL (ed) The economy of lower Yangzi Delta in late imperial China. Routledge, London, pp 17-71

Von Glahn R (2016) The economic history of China from antiquity to the nineteenth century. Cambridge University Press, Cambridge

Wang Y-c (1979) Evolution of the Chinese monetary system, 1644-1850. In: Hou C-M, Tzong-Shiang Y (eds) Modern Chinese Economic History (proceedings of a conference). Institute of Economics, Taipei, pp 425-452

Wang Y-c (1992) Secular trend of rice prices in the Yangtze Delta, 1638-1935. In: Rawski T, Li L (eds) Chinese history in economic perspective. University of California Press, Berkeley, pp 35-68

Yamamura K, Kamiki T (1983) Silver mines and sung coins: a monetary history of medieval and modern Japan in international perspective. In: Richards JF (ed) Precious metals in the late medieval and early modern worlds. North Carolina Academic Press, Durham, pp 329-362

Yang L-S (1952) Money and credit in China: a short history. Harvard University Press, Cambridge 